\title{
BURROWING CENTRAL AMERICAN MANGROVE LAND CRABS AND THEIR BURROW ASSOCIATES
}

\author{
by
}

\author{
DONALD B. BRIGHT 1)
}

\begin{abstract}
General remarks on the following aspects of the life history of land crabs are presented: migration, shedding of eggs, molting, juveniles and food. The nature of the crab burrows and the associated burrowdwelling organisms also are presented. The distribution of burrowing land crabs is discussed with respect to three general plant formations in gecarcinid crab localities, ie., Mangrove-Estero, Island and Strand patterns.
\end{abstract}

\section{INTRODUCTION}

Land crabs are common denizens of tropical coastal areas. They are most common in mud flat and mangrove areas where they construct burrows. Yet, in spite of their abundance, published data have consisted mainly of species accounts and selected aspects of behavior and natural history (BRIGHT 1966; CRANE 1947; CROSNIER 1965; GARTH 1960; GIFFORD 1963; HERREID \& GifFord 1963; Hogue \& Bright 1969; MANNING \& PROVEnZANo 1961; SilAS \& SANKARANKUTTY 1960; VillalobOS \& CABRERA 1964; and WRIGHT 1966). The first account of the unique ecological relationship between burrowing land crabs, general habitat types and a variety of associated burrow organisms was published by BRIGHT \& HoGUE (1974). This account was based on a series of studies conducted in the American tropics starting in 1964.

The general discussion which follows is based on data obtained at nine (9) primary study sites between 1964 and 1975: La Paz, Baja California Sur; Boca de Barranca, Costa Rica; Tumbes, Peru: Santos, Brazil; Limon, Costa Rica; Isla San Andres, Columbia; Florida, U.S.A.; Kilifi Creek, Africa; and the Ryukyus Islands. All reference to season or month of year refer to data from study sites in central America.

\section{LAND CRABS}

The term land crab is used for a number of species. Taxa commonly considered as such belong to the following families: Gecarcinidae, Ocypodidae, Grapsidae and Coenobitidae (Table I). Among these families many

1) Director of Environmental Affairs, Port of Long Beach, California. 
DONALD B. BRIGHT

Table I. Species of Land Crabs

\section{Family: COENOBITIDAE}

Family: GRAPSIDAE

Family: OCYPODIDAE

Ucides cordatus

Ucides occidentalis

Family: GECARCINIDAE

Gecarcoidea humei

Cardisoma guanhumi

Cardisoma crassum

Cardisoma armatum

Cardisoma carnifex

Cardisoma hirtipes

Gecarcinus planatus

Gecarcinus ruricola

Gecarcinus quadratus

Gecarcinus lateralis

species are non-burrowers, e.g. terrestrial hermit crabs of the family Coenobitidae, and selected species of Grapsidae and Ocypodidae.

In general land crabs dwell on land under debris, in the notches of trees, under the edges of cliffs, in holes dug by other animals, and in selfconstructed burrows. Although all of these crabs are "chained" to the ocean because they possess typical marine zoeal larvae, their degree of dependence on water (fresh and brackish) varies during juvenile and adult stages from almost total, as in the case of Ucides spp., to none except during larval release, as in the case of certain species of Gecarcinus. Certain species almost never construct burrows or dwell in depressions, e.g. terrestrial hermit crabs (Coenobitidae). Some are very cryptic utilizing natural hiding spots such as under decaying vegetation, coconut husks, and logs, e.g. Gecarcinus spp., 
while others construct well defined burrows which may be shallow and dry (Gecarcinus spp.) or deep and partially filled with water derived from ground seepage and/or rainfall (Cardisoma spp.). Herein the discussion is generally restricted to those forms which construct well-defined burrows, dwell in or immediately adjacent to mangroves, and belong to the families Ocypodidae and Gecarcinidae (Table I).

\section{SYNOPSIS OF LIFE HISTORY}

Several accounts on selected aspects of land crab life history are conflicting, principally where the investigation has centered on burrow inhabitants, e.g., mosquitoes. Also, there are discrete variations in behavior between varying geographical areas, such as La Paz, Baja California Sur versus Tumbes, Peru or Boca de Barranca (Pacific Coast) versus Limon (Atlantic Coast), Costa Rica. The discussion which follows is generalized.

1. Migration. During much of the year juveniles and adults occur in individual burrows while smaller individuals $1.0 \mathrm{~mm}$ to $12.0 \mathrm{~mm}$ in carapace length are cryptic but often in small aggregations of two to twelve individuals. Beginning in mid-spring (April in Central America) sexually mature indivi duals migrate toward the sea shore. Often the migration becomes intense with $10-20$ individuals per square meter $30-40$ days after the start of migratory moment. In heavily populated areas the crab suffers from massive mortality either from predation (mostly birds) or conflict with human activity, e.g., along roads and on airport runways. In general the migrations are completed after $40 \sim 60$ days. The degree of migratory behavior is inversely proportional to the degree of terrestriality. Certain members of the genera Cardisoma and Gecarcinus illustrate the most exten sive migratory behavior. After shedding of the eggs, the crabs return to the pre-migratory habitat areas, but by a slower, more individualistic pattern. To date there is no evidence of homing behavior. In some instances large numbers of individuals move away from the sea during peak migratory beha vior; in certain areas, such as in Florida, this behavior pattern is fairly com mon. To date there is no explanation for this behavior although it occurs most frequently in areas where the terrain has been substantially altered by human activity.

2. Shedding of Eggs. Females carry the eggs beneath their abdomen attached to the pleopods for one year. During that time the eggs develop into zoeal larvae. At the culmination of migration, the females enter the water. Hatching is induced by submerging the egg laden abdomen beneath 
the water. This causes the egg cases to rupture allowing the zoea to swim away.

3. Molting. While the eggs are being shed, sexually mature males molt. Molting is accomplished in darkness, that is in a burrow, under a rock or coconut husk, etc. After shedding of the eggs, copulation occurs before the females molt. Males often assist the females. Females also require darkness to complete molting. Molting has been observed in areas immediately adjacent to the water as well as in pre-migratory localities. More study is needed, however to determine the specific relationship between migration, shedding of eggs, molting and fertilization.

Some species which construct dry burrows, e.g. Gecarcinus spp., have evolved a specialized mode of obtaining and storing the volume of water needed during molting and other phases of ecdysis. BLISs (1964) gives a concise account of this process.

4. Juveniles. Behavior of juveniles has not been well documented. Pre sumably, they molt frequently for the first two to three months, while the frequency of sequential molts decrease with increasing age. However, after reaching sexual maturity, at least females must molt annually in order to breed.

5. Food. Most of the burrowing land crabs are scavengers utilizing such items as blue-green algae (Calothrix spp.), fungi (Daldinia spp.), various beetles, leaves of mangroves (both new and decayed), etc. There is a tendency toward vegetarianism with an increased degree of burrow construction.

\section{BURROWS}

There is considerable variation in burrows - between species and different age groups within the same species. Some burrows are open depressions while others extend $3-4$ meters below the surface. In general, they are a gently sloping or nearly vertical tubular excavation. The diameter of the burrow is generally equivalent to the width of the carapace of the occupant. Figure 1 shows a generalized view of the burrow of Cardisoma spp. Some species continually clean out the burrows, e.g. Cardisoma crassum while others only enlarge the burrow as a function of growth, e.g. Gecarcinus ruricola, or due to an increased or reduced volume of water in the burrow reservoir, e.g. Ucides occidentalis. There is no evidence that Central American land crabs (Cardisoma crassum and C. guanhumi) construct 
BURROWING CENTRAL AMERICAN MANGROVE

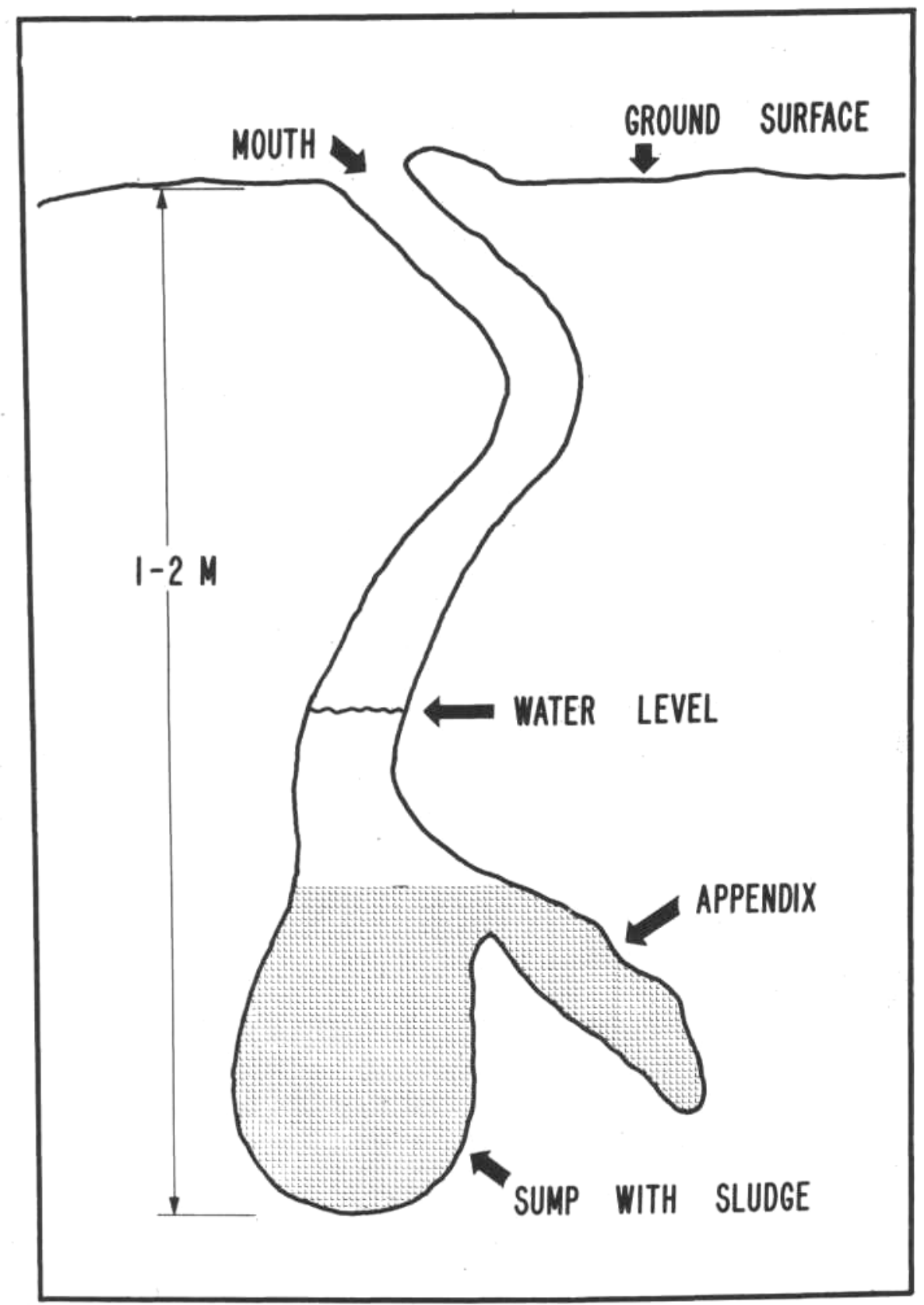

Figure 1. Generalized burrow of Cardisoma spp. 
"castles" with interconnecting burrow systems as noted for species of Cardisoma in portions of Africa and the Indo-Pacific (SILAS \& SANKARANKUTTY 1960).

Some species, e.g. Gecarcinus, are so well adapted for a terrestrial existence that their burrows are for physical protection only and penetration of the burrow to the water table to maintain a supply of water is not necessary (BLISS 1964). In contrast others, e.g. Ucides occidentalism construct burrows in mangrove swamps where tidal effects in the reservoir volume are noticeable.

\section{BURROW ASSOCIATES}

Many organisms occur in the burrows of land crabs, and are associated ecologically with the crab. All such are called the "crabhole community" (BRIGHT \& HOGUE 1972) .

This community can be grossly divided into two components (Table II) : those associated with dry burrows and those in moist, reservoir-containing burrows.

Table II. Crabhole Community*

I. Associated with Dry Burrow:

Mites (Laelaps cancer)

Fruitflies (Drosophila carcinophila)

Adult mosquitoes (e.g. Culex spp., Deinocerites spp.)

Amblypygidids

Gnats (Culicoides spp.)

II. Associated with Moist, Reservoir - Containing Burrow :

Diving Beetles (Bidessus spp.)

Larvae and Pupae of Mosquitoes (Deinocerites spp.,

Culex spp., Aedes spp., etc.)

* from BRIGHT \& HogUe 1972

Also, the extent to which a particular organism is dependent on the burrow as a suitable habitat, and the extent it is an obligate member of the community can be further classified (BRIGHT \& HOGUE: 1972): 
1. Specific or obligatory - where a species is adapted to the variable conditions in the burrow or lives symbiotically, e.g. Drosophila larvae living on the peribuccal region of Gecarcinus ruricola.

2. Semispecific or semiobligatory — species which usually inhabit bur rows, but which survive well in other habitats, e.g. the mosquito Aedes (Skusea) pembaensis which breeds in burrows, pools, swamps, etc.

3. Transient or facultative - species which temporarily occur in the crabhole because of proximity to the normal habitat, e.g. the mosquito Culex (Culex) annulirostris an indiscriminate breeder.

4. Accidental - species found in burrows for an anomalous reason, e.g. adult Mansonia mosquitoes whose life history does not coincide with burrow conditions.

A more nearly complete discussion of these four categories can be found in BRIGHT \& HOGUE (1972).

\section{DISTRIBUTION}

Land crabs are common in tropical coastal areas. Specific distribution for each species varies with a general functional mix of factors such as soil composition, proximity to brackish or salt water, food availability, available protection, degree of terrestriality, maximum size as an adult, age, sex, and so forth. Further, plant formations leading to climactic states support greater numbers of individuals.

Varying degrees of terrestriality, aside from age differences, are clearly discernable among the common genera. Gecarcinus spp. is the most terrestrial form occupying shallow dry burrows, hiding under debris, rocks or tree roots, either very close or up to $3-4 \mathrm{~km}$ away from the coast. In addition, island forms among the various species of Gecarcinus occur in dryer, more exposed areas than mainland counterparts. Cardisoma spp. occurs in moist areas where the burrows are deep and with a reservoir, such as in the higher, dryer areas in mangroves. Ucides spp. also occur in mangrove areas, but in areas that almost always are covered by the highest high tide.

All the burrowing land crabs commonly occur in areas with compact, cohesive alluvial soils. Table III shows the number of grams by grain size for samples taken from nine (9) stations in three (3) different localities. Table IV gives the per cent of grains $<0.104 \mathrm{~mm}$ and $>0.104 \mathrm{~mm}$ together with the occurrence of land crabs. Note that stations 1, 2, 3, 5, 6 and 7 are in well defined mangroves, station 4 is on a partially "decayed" coral reef, 


\section{DONALDB. BRIGHT}

and stations 8 and 9 are from the upper edge of a mangrove adjacent to an arid, cactus-populated desert. The composition of larger grain sizes for stations 8 and 9 is due to the fact that the finer grains are carried away by the continually strong winds characteristic of the area.

Table III. Grain sizes for nine (9) samples taken from land crab burrow walls

\begin{tabular}{|c|c|c|c|c|c|c|}
\hline \multicolumn{7}{|c|}{ Mesh } \\
\hline Locality & $3.327 \mathrm{~mm}$ & $0.991 \mathrm{~mm}$ & $0.841 \mathrm{~mm}$ & $0.104 \mathrm{~mm}$ & $0.053 \mathrm{~mm}$ & smaller \\
\hline $\begin{array}{l}\text { Boca de Barranca, } \\
\text { Costa Rica }\end{array}$ & $0.00 \mathrm{~g}$ & $0.02 \mathrm{~g}$ & $0.05 g$ & $7.11 \mathrm{~g}$ & $4.10 \mathrm{~g}$ & $2.58 \mathrm{~g}$ \\
\hline $\begin{array}{l}\text { Boca de Barranca, } \\
\text { Costa Rica }\end{array}$ & $0.00 \mathrm{~g}$ & $0.04 \mathrm{~g}$ & $0.02 \mathrm{~g}$ & $14.68 \mathrm{~g}$ & $4.77 \mathrm{~g}$ & $1.18 \mathrm{~g}$ \\
\hline $\begin{array}{l}\text { Playa del Coco, } \\
\text { Costa Rica }\end{array}$ & $0.00 \mathrm{~g}$ & $0.91 g$ & $0.42 \mathrm{~g}$ & $10.20 \mathrm{~g}$ & $3.22 \mathrm{~g}$ & $2.60 \mathrm{~g}$ \\
\hline $\begin{array}{l}\text { Isla San Andres, } \\
\text { Columbia }\end{array}$ & $3.44 \mathrm{~g}$ & $3.15 \mathrm{~g}$ & $0.34 \mathrm{~g}$ & $1.20 \mathrm{~g}$ & $0.21 \mathrm{~g}$ & $0.21 \mathrm{~g}$ \\
\hline $\begin{array}{l}\text { Isla San Andres, } \\
\text { Columbia }\end{array}$ & $0.00 \mathrm{~g}$ & $0.31 \mathrm{~g}$ & $0.24 \mathrm{~g}$ & $5.99 \mathrm{~g}$ & $4.15 \mathrm{~g}$ & $6.47 \mathrm{~g}$ \\
\hline $\begin{array}{l}\text { Isla San Andres, } \\
\text { Columbia }\end{array}$ & $0.45 \mathrm{~g}$ & $2.71 \mathrm{~g}$ & $0.65 g$ & $9.61 \mathrm{~g}$ & $2.36 \mathrm{~g}$ & $2.42 \mathrm{~g}$ \\
\hline \begin{tabular}{|l} 
La Paz, Baja \\
California Sur
\end{tabular} & $2.35 \mathrm{~g}$ & $4.14 \mathrm{~g}$ & $0.83 g$ & $9.76 \mathrm{~g}$ & $1.71 \mathrm{~g}$ & $1.49 \mathrm{~g}$ \\
\hline $\begin{array}{l}\text { La Paz, Baja } \\
\text { California Sur }\end{array}$ & $3.12 \mathrm{~g}$ & $5.02 \mathrm{~g}$ & $0.91 \mathrm{~g}$ & $8.03 \mathrm{~g}$ & $2.62 \mathrm{~g}$ & $2.58 \mathrm{~g}$ \\
\hline \begin{tabular}{|l} 
La Paz, Baja \\
California Sur
\end{tabular} & $7.00 \mathrm{~g}$ & $4.66 \mathrm{~g}$ & $0.46 \mathrm{~g}$ & $2.27 \mathrm{~g}$ & $0.62 \mathrm{~g}$ & $0.79 g$ \\
\hline
\end{tabular}


Table IV. Relationship between soil grain sizes and abundance of land crabs

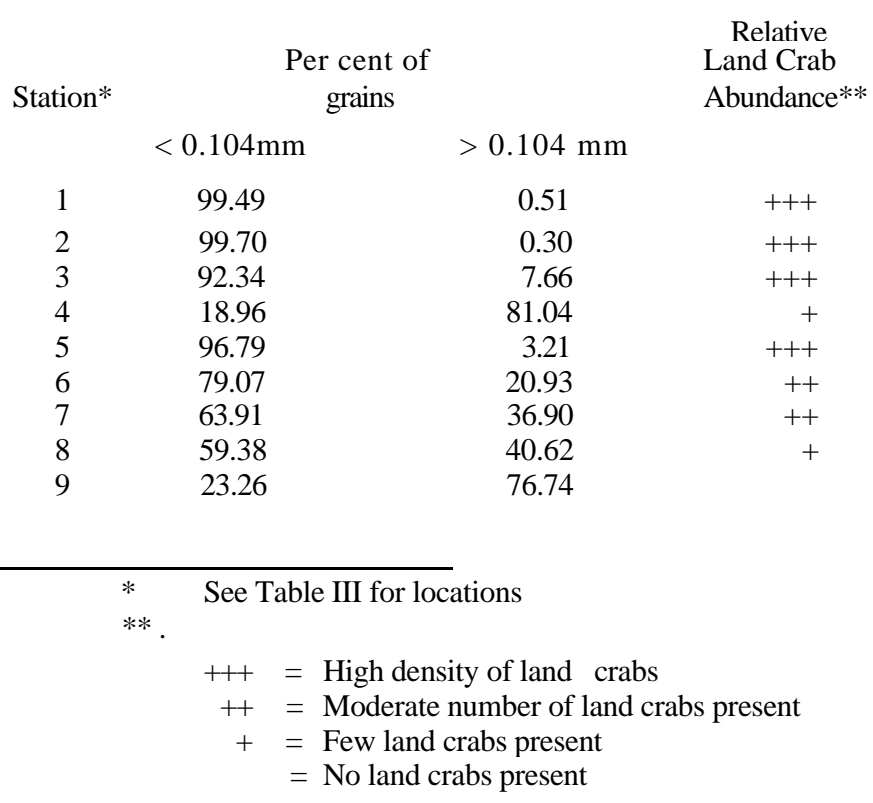

The relationship between certain plant formations and adult gecarcinid crabs is frequently quite evident provided that the plant formation occupies more than 0.1 hectare. This relationship, even though it is temporal, is discernable into three (3) patterns: Mangrove-Estero, Island and Strand.

These patterns are summarized in Figures 2 and 3. Typical Central American vegetation listed for each pattern is highly generalized, and there is considerable local variance in plant species composition.

1. Mangrove-Estero. This pattern is characterized in Central America by a mangrove community during mid-succession (well established but not climactic) where vegetation zones beginning at the water and proceeding inward to dry land (above the highest high tide) are : Rhizophora sp., Avicennia sp. and Hibiscus sp. Figures 2 gives other genera which are common.

The burrowing mangrove land crabs are distributed above or below the highest high tide (HHT). Species of Ucides occur below the HHT (Zone A, Fig. 2) and those of Cardisoma occur above the HHT (Zone B, Fig. 2). The distance above the HHT where burrows occur depends on the nature 


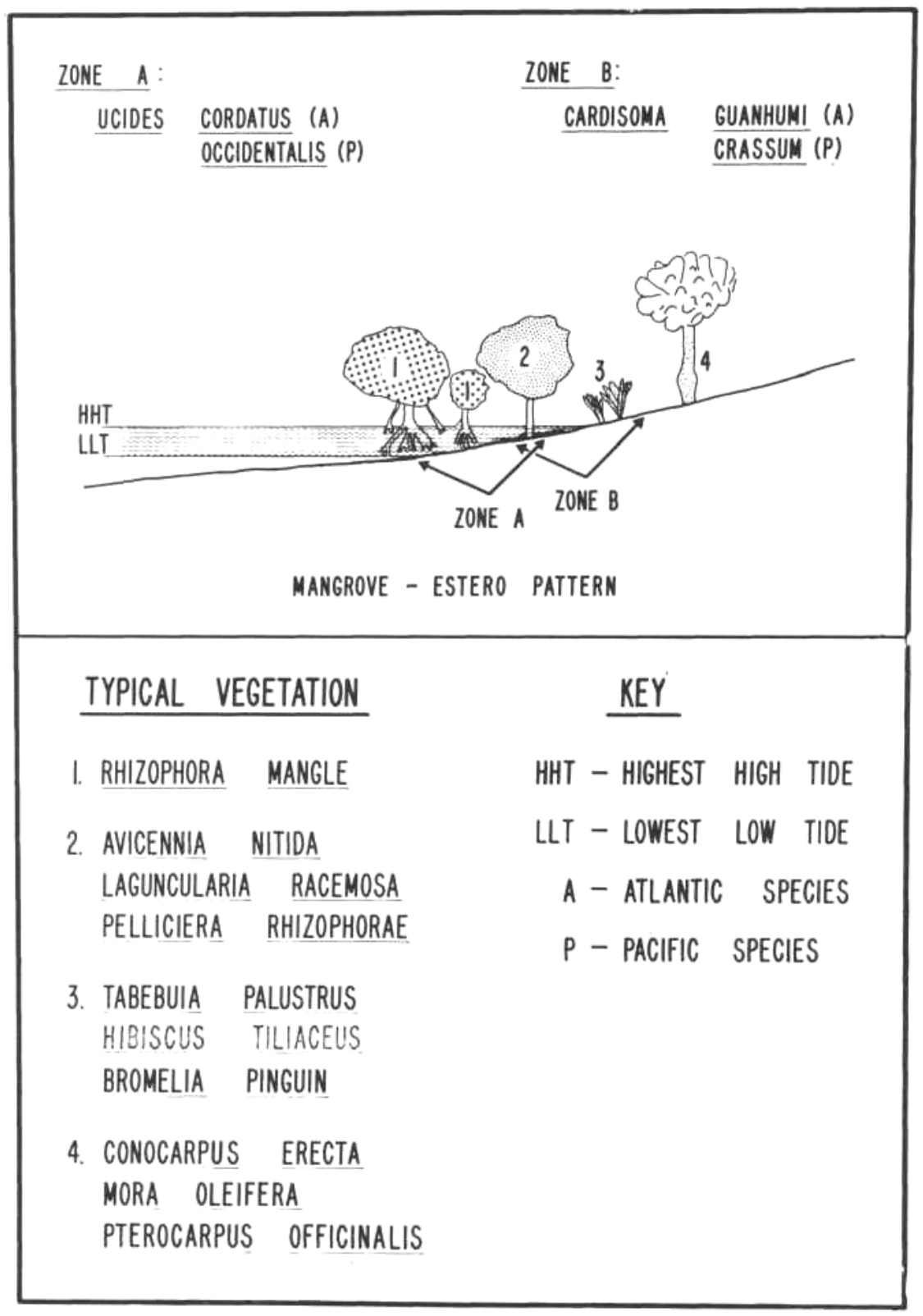

Figure 2. Mangrove-Estero plant formations in gecarcinid crab habitats. 


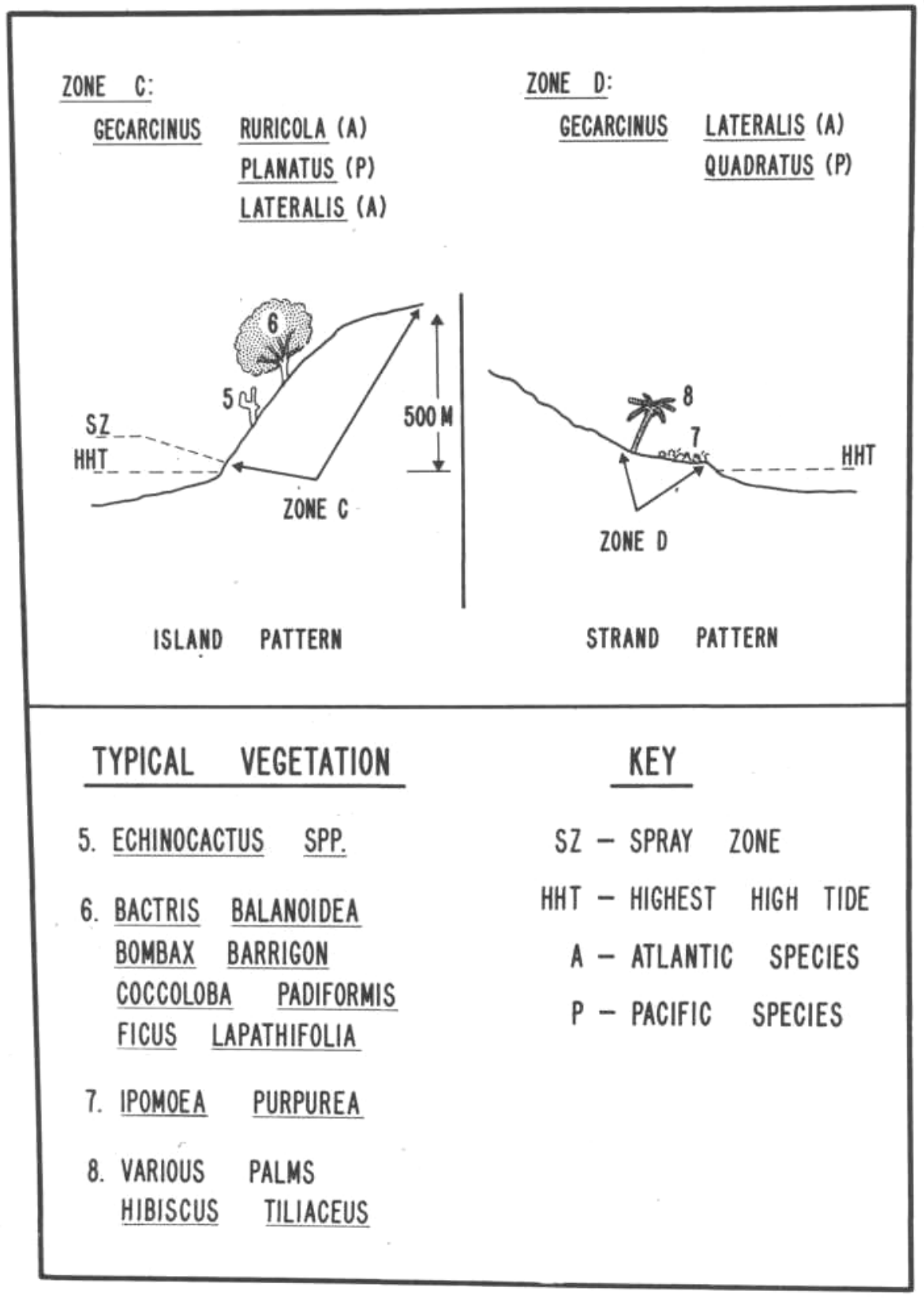

Figure 3. Island and Strand plant formations in gecarcinid crab habitats. 
of the substrate and whether a burrow can be constructed to reach the water table.

In Central America there are twin or geminate species, e.g. Cardisoma guanhumi on the Atlantic Coast and Cardisoma crassum on the Pacific coast. There are similar twin species patterns for the species of the genus Gecarcinus. Figures 2 and 3 show such species.

2. Island Patterns. Through isolation on islands off both the Pacific and Atlantic coasts of Central America, distinct species of crabs (as well as twin species) have evolved. The vegetation associated with land crabs on islands is highly variable. The extremes are noted in Figure 3, e.g., Enchinocactus spp. and Bombax barrigon.

The crabs do not construct well defined burrows, but well under rocks, in crevices between tree roots, etc. They occur from the spray zone (just above the HHT) to inland areas as far as $3-4 \mathrm{~km}$ away from the ocean. They have been found at altitudes 500 meters above the HHT.

3. Strand. Along coastal mainland areas there are "strand situations" characterized by sandy accumulations covered by low growing halophytic forms, e.g. Ipomoea purpurea, which only are disturbed by extremely highhigh tides. In such areas there are land crabs which construct shallow bur rows or live in depressions under rocks, logs, etc. The degree of terrestriality exhibited by crabs occurring in strand areas is comparable to that of crabs associated with the Island pattern. One Central American species, Gecarcinus lateralis is found in both Island and Strand situations.

Crabs associated with both the Island and Strand situation are quite terrestrial and have evolved special means of obtaining and internally storing the volume of water needed to successfully complete molting (see BLISS 1969 for a thorough discussion).

Based on the three distribution patterns, the twelve species of land crabs listed in Table I occur as follows :

MANGROVE-ESTERO : Ucides cordatus and U. occidentalis; Gecarcoidea humei; Cardisoma guanhumi, C. crassum, C. armatum, C. carnifex, and C. hirtipes.

ISLAND PATTERN: Gecarcinus ruricola, $G$, planatus, and G. lateralis.

STRAND PATTERN : Gecarcinus lateralis and G. quadratus. 


\section{ACKNOWLEDGMENT}

Since 1964, Dr. Charles L. Hogue, Los Angeles Country Museum of Natural History, and I have visited a number of areas to study land crabs. Such studies have been based on mutual respect; therefore, his knowledge and personal interest have contributed substantially to the content of this paper.

\section{BIBLIOGRAPHY}

BLISS, D.D. 1964. Environmental regulation of growth in the Decapod Crustacean Gecarcinus lateralis. Gen. Comp. Endocrinol. 4 :15 - 41.

Bright, D.B. 1966. The land crabs of Costa Rica. Rev. Biol. Trop. 15 : 183 - 203.

BRIGHT, D.B. and C.L. HOGUE 1972. A synopsis of the burrowing land crabs of the world and list of their arthropod symbionts and burrow associates. Los Angeles Co. Mus., Contrib. Sci. 220.

CRANE, J. 1947. Eastern Pacific expeditions of the New York Zoological Society XXXVIII. Intertidal Brachygnathous crabs from the west coast of tropical America with special reference to ecology. Zoologica $32: 69$ - 95.

CROSNIER, A 1965. Crustaces Decapodes Grapsidae et Ocypodidae. Faune de Madagascar 18 : 1 143.

GARTH, J.S. 1960. Distribution and affinities of the brachyuran Crustacea. (Symposium : The biogeography of Baja California and adjacent seas. Part II. Marine biotas). Syst. Zool. 9-105 $-123$.

GIFFORD, C.A 1963. Some observations on the general biology of the land crab, Cardisoma guanhumi (LATREILLE) in South Florida. Biol. Bull. 123 :207-223.

HERREID, C. F. and C.A GIFFORD 1963. The burrow habitat of the land crab, Cardisoma guanhumi (LATREILLE). Ecology 44 :773 - 775.

Hogue, C. L. and D.B. BRIGHT 1969. Study of the biology of land crabs and their burrow associates. Assoc. Trop. Biol. Newsletter $18: 9$ - 11-

MANNING, R.B. and AJ. ProvenZANo 1961. The occurrence of Ucides cordatus (Linnaeus, 1963) (Decapoda) in the United States. Crustaceana 2: 158 - 159.

Silas, E.G. and C. SAnKARAnKutty 1960. On the castle building habit of the crab Cardisoma carnifex (HERBST) (Family Gecarcinidae) of the Andaman Islands. J. Mar. Biol. Assoc. India 2 : 237 - 240.

Villalobos, A .and J. CABRERA 1964. Los cangrejos del genero Gecarcinus como un peligro potencial para la agricultura de las zonas aledanas a nuestros litorales. Folia Entomol. Mexicana 7 - $8: 27$ - 29.

WRight, HO. I960. Comparative studies of social behavior in grapsoid crabs. Ph. D. Dissertation, Univ. California, Berkeley, 226 pp. 